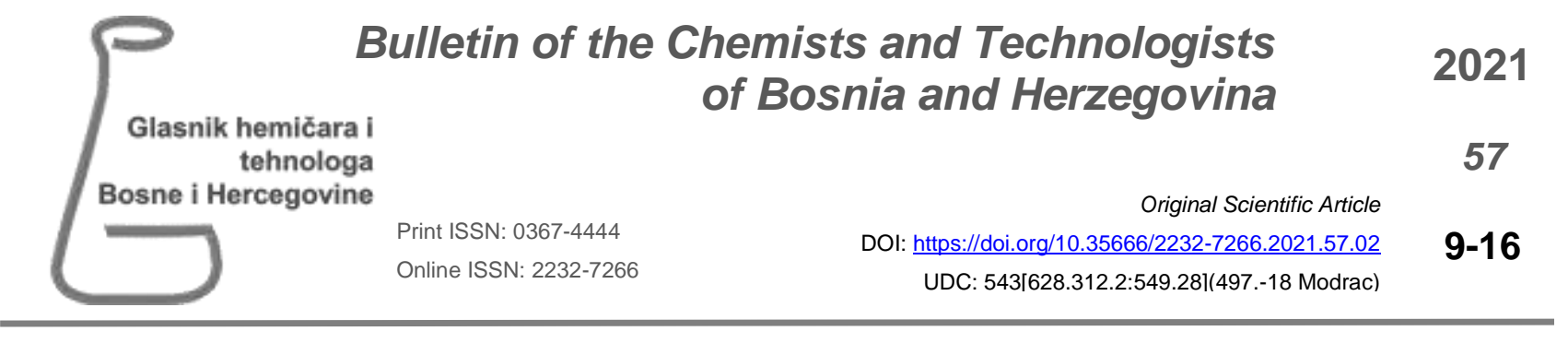

\title{
Occurrence of the heavy metals and PCBs in Accumulation Lake Modrac
}

\author{
Marjanovic, A.*, Djedjibegovic, J., Omeragić, E., Sober, M.
}

Faculty of Pharmacy, University of Sarajevo, Zmaja od Bosne 8, 71 O00 Sarajevo, BiH

Article info

Received: $14 / 06 / 2021$

Accepted: 13/12/2021

Keywords:

Accumulation

Lake Modrac

PCBs

heavy metals

\begin{abstract}
The accumulation Lake Modrac is a particularly important source of drinking water for inhabitants of the Tuzla region and few local settlements. The most significant point sources of organic contaminants in the accumulation Lake Modrac are waste water from households and industry. In this area, most of the settlements have neither sewage systems nor facilities for waste water treatment. Other potential point sources of pollutants are industrial plants. The most prominent are coal mines (Banovići and Đurđevik), metal and wood industry, plant for plastic production, and oil and oil derivatives warehouse. Few previously conducted surveys in the region showed the presence of the persistent organic pollutants and heavy metals in large extent. The objective of this study was to conduct a water quality survey targeting selected inorganic $(\mathrm{Cd}$, $\mathrm{Cr}, \mathrm{Cu}, \mathrm{Hg}, \mathrm{Ni}, \mathrm{Pb}$ and $\mathrm{As}$ ) and organic pollutants in the accumulation Lake Modrac in Bosnia and Herzegovina. The content of polychlorinated biphenyls (PCBs) determined with ELISA test, ranging from 3.23 to $6.19 \mu \mathrm{g} / \mathrm{L}$ (sum of 7PCBs). The most abundant metals (analyzed by graphite furnace AAS and mercury analyzer) at all five sampling locations were $\mathrm{Pb}(6.79-36.58 \mu \mathrm{g} / \mathrm{L})$; $\mathrm{Ni}$ (5.81-10.43 $\mu \mathrm{g} / \mathrm{L})$ and $\mathrm{Hg}(1.08-6.10 \mu \mathrm{g} / \mathrm{L})$.
\end{abstract}

*Corresponding author: Aleksandra Marjanović E-mail: aca1902@gmail.com Phone: +387 61709562
All these facilites discharges mainly untreated wastewater into the Lake Modrac or its tributaries. The useful volume of accumulation is limited, primarily due to prolonged deposition of coal dust from coal mines in the basin reservoirs (Strategy, 2012).

The diffuse sources of pollution of the accumulation Lake Modrac with persistent organic pollutants (POPs) are chemical contamination of land used for agricultural production, unregulated landfill for municipal and industrial waste, forestry, transportation, atmospheric deposition of air pollutants, leaching from urban surfaces and industrial areas and others.

In the area of the Bosna River basin, there is a high number of landfills that often contain medical waste (beside municipal and industrial waste), which poses a significant risk and affects the water quality.

Uncontrolled landfills for municipal and other waste are very often the source of fires causing the emission of large quantities of toxic pollutants, including polychlorinated biphenyls (PCB), polychlorinated metal and wood industry, plant for plastic production, oil, and oil derivatives warehouse. 
dibenzodioxins (PCDD) and polychlorinated dibenzofurans (PCDF).

During the war (1992-1995) in Bosnia and Herzegovina, large amounts of POPs were generated and emitted into the environment because of partial or complete destruction of industrial facilities, military targets, infrastructure, explosions, and uncontrolled fires (Klánová, Kohoutek, Kostrhounová, et al., 2007).

Persistent pollutants are suspected to be a potential problem in major rivers in Bosnia and Herzegovina. However, very little information exists on persistent pollutants contamination as very little analyses have been done (Harman, Grung, Djedjibegovic, et al., 2013; Harman, Grung, Djedjibegovic, et al., 2018).

Studies of environmental quality or water quality of Lake Modrac dated back after the war (latest data are from 1991) and are scarce. In 2016 investigation that was conducted by the Institute for chemical engineering Tuzla (as ordered by public water management company Spreča-Tuzla) showed worsening of all physicochemical parameters of water quality in Lake Modrac comparing to similar investigations done in 2015 (Institute for chemical engineering, 2016). According to legislation in Federation of Bosnia and Herzegovina $(\mathrm{FBiH})$, Lake Modrac should be categorized as class II water, meaning that after physical treatment, chemical treatment, and disinfection this water can be used as drinking water, for aquaculture of Salmonids or for the recreative purposes (swimming or sport) (Directive, 1967).

Results of physicochemical analysis of surface water (JP Spreča dd, laboratory) conducted in 2017 showed that water from the Lake Modrac can be classified as class II, III, IV, or sometimes even non categorized (mouth of River Spreča into a Lake Modrac). Regarding to content of total suspended solids (TSS) it can be categorized as class IV (Reports JP Spreča, 2017). High content of TSS is usually due to contamination with wastewater, or it can point to diffuse sources (i.e., agricultural activities). Calculated chemical oxygen demand/biochemical oxygen demand $\left(\mathrm{COD} / \mathrm{BOD}_{5}\right)$ ratio was 5.21-8.9 (usually is 1.5-3.0; in extreme cases >5) (Reports JP Spreča, 2017) and is obvious sign of pollution. Inversely, $\mathrm{BOD}_{5} / \mathrm{COD}$ ratio calculated from the above presented data from JP Spreča Report is $0.11-0.19$. BOD $_{5} / \mathrm{COD}$ ratio $0-0.5$ can suggest presence of persistent organic compounds (i.e., coal dust, lignins, tannins, cellulose, synthetic organic compounds) (Lee, Lee, Yu, et al., 2016).

Heavy metals and POPs can pose a significant risk for the environment and human health. So far, great number of studies have linked exposure to POPs with diseases and abnormalities in wildlife species, including fish, birds and mammals. In humans POPs can cause variable adverse health effects, especially, reproductive, neurological, behavioral, immunological and endocrine (Li, Loganath, Chong, et al., 2006; Kumar, Kumar Sarma, Shubham, et al., 2020).

Literature data suggest that all classes of POPs including PCBs and other pollutants like some heavy metals/metalloids, such as $\mathrm{Cd}, \mathrm{Pb}, \mathrm{Hg}$ and $\mathrm{As}$ can be classified as endocrine disrupting compounds (EDCs). For example, according to results of previously conducted studies, exposure to low levels of certain essential or trace metals (i.e., $\mathrm{Cu}, \mathrm{Cr}$ ) can also be related to adverse effects on reproduction in humans (Ashrap, Meeker, Sánchez, et al., 2020; Street, Angelini, Bernasconi et al., 2018; Street, Angelini, Bernasconi, et al., 2018; Nwadiuto Amadi, Nkeiruka Igweze, Ebere Orisakwe, 2017). Special problem is possible additive toxicity as result of exposure to a mixture of toxicants that can act on the same organs or tissues.

Bearing this in mind, the surveillance of specific pollutants, representing the level of anthropogenic impact in the water bodies, is necessary for chemical water body status classification. Among others, preserving and protecting the "'good status" for all waters, surface and groundwater, is one of the main goals of Water Framework Directive (WFD) (EC, 2000). Survey and monitoring data are important basis for sound management of the water resources. Therefore, the objective of this study was to conduct a water quality survey targeted on selected inorganic $(\mathrm{Cd}, \mathrm{Cr}, \mathrm{Cu}, \mathrm{Hg}$, $\mathrm{Ni}, \mathrm{Pb}$ and $\mathrm{As}$ ) and organic pollutants (PCBs) in the accumulation Lake Modrac in Bosnia and Herzegovina.

\section{EXPERIMENTAL}

\section{Sampling}

Samples $(\mathrm{N}=5)$ analyzed in this work were taken from different locations at accumulation Lake Modrac in August 2018. Sampling sites are presented in Table 1.

Table 1. Sampling locations at accumulation Lake Modrac

\begin{tabular}{lcc}
\hline Sample & Locations & Coordinates \\
\hline M1 & Mouth of River Turija & $44^{\circ} 30^{\prime} 31.6^{\prime \prime} \mathrm{N}$ \\
& & $18^{\circ} 27^{\prime} 53.6^{\prime \prime} \mathrm{E}$ \\
M2 & Trnovčica & $44^{\circ} 29^{\prime} 40.2^{\prime \prime} \mathrm{N}$ \\
& & $18^{\circ} 30^{\prime} 05.1^{\prime \prime} \mathrm{E}$ \\
M3 & Mouth of River Spreča & $44^{\circ} 28^{\prime} 42.2^{\prime \prime} \mathrm{N}$ \\
& & $18^{\circ} 32^{\prime} 30.6^{\prime \prime} \mathrm{E}$ \\
M4 & Prokosovići & $44^{\circ} 30^{\prime} 37.0^{\prime \prime} \mathrm{N}$ \\
& & $18^{\circ} 29^{\prime} 01.1^{\prime \prime} \mathrm{E}$ \\
M5 & Behind the dam of & $44^{\circ} 30^{\prime} 57.0^{\prime \prime} \mathrm{N}$ \\
& company "Spreča" & $18^{\circ} 30^{\prime} 37.9^{\prime \prime} \mathrm{E}$ \\
\hline
\end{tabular}

For the metal analysis, water samples (2 L) were taken in clean plastic bottles, stabilized by adding $2 \mathrm{ml}$ of concentrated nitric acid (67-69\% $\mathrm{HNO}_{3}$, Optima grade, Fisher Scientific, UK) and stored in refrigerator $\left(4{ }^{0} \mathrm{C}\right)$ prior the analysis. All the samples were analyzed in triplicate.

For the analysis of PCBs water samples ( $1 \mathrm{~L})$ were collected in glass containers, previously washed with methanol (extra pure, Fisher Scientific, UK), and dried in the oven $\left(400{ }^{0} \mathrm{C}\right)$ for a couple of hours. Containers were fitted with the foil-lined screw caps. Samples were diluted with the equal volume of methanol to prevent adsorptive losses.

\section{Materials}

All used chemicals were of ultra-pure grade. The water $\left(18.2 \mu \mathrm{Scm}^{-1}\right)$ used for the preparation of reagents and standards was obtained from a laboratory water purifying system (Arium 611, Sartorius Mechatronics, Goettingen, Germany). 
All the glassware and utensils used for the metal analysis were washed with the ultra-pure water, after soaking in $10 \% \mathrm{HNO}_{3}$ for $24 \mathrm{~h}$

All the glassware and utensils used for the analysis of PCBs were washed with ultra-pure water, rinsed with methanol and dried $\left(400{ }^{\circ} \mathrm{C}\right)$ in the oven for a couple of hours.

\section{Sample preparation for heavy metal analysis}

For the analysis of heavy metals/metalloids $(\mathrm{Pb}, \mathrm{Cd}$, total $\mathrm{As}, \mathrm{Cu}, \mathrm{Cr}, \mathrm{Ni}$ ), samples were digested in the microwave oven Ethos D 118 (Milestone, Sorisole, Italy) in accordance with standard method (BAS EN 13805:2015) previously described by Omeragić et al. (Omeragic, Radosevic, Causevic, et al., 2021).

\section{Analysis of selected heavy metals}

Analysis of the selected heavy metals in water samples was performed at the laboratory of the Institute for Public Health of the Federation of Bosnia and Herzegovina. For the determination of $\mathrm{Pb}, \mathrm{Cd}$, total $\mathrm{As}$, $\mathrm{Cu}, \mathrm{Cr}$ and $\mathrm{Ni}$ graphite furnace atomic absorption spectrometry (GFAAS) analysis was performed using the atomic absorption spectrometer AA-7000F Dual Atomizer System (Shimadzu, Tokyo, Japan), equipped with self-reversal method (SR) background correction. For the removal of residues from the graphite tube during pyrolysis, argon flow was used. Analysis was done using the standard method for the determination of trace metals using GFAAS (BAS EN ISO 15586:2005). The content of $\mathrm{Hg}$ was determined using AMA 254 advanced mercury analyzer (Leco Inc., USA) with the in-house method. Briefly, the sample was directly measured (ranged between 0.1 and $0.5 \mathrm{ml}$ ) into the precleaned sample boat and placed in the instrument. The $\mathrm{Hg}$ concentration was determined using the principle of thermal decomposition, amalgamation, and atomic absorption spectrometry at $254 \mathrm{~nm}$ wavelength. A standard solution of $\mathrm{Hg}(1000 \mathrm{mg} / \mathrm{L} \pm 2 \mathrm{mg} / \mathrm{L}$, Merck KGaA, Darmstadt, Germany) was diluted with $\mathrm{HNO}_{3}$ to obtain working solutions for preparation of calibration curves (2.5-30.0 ng and 100-500 ng).

Table 2. Parameters of used analytical methods

\begin{tabular}{lcccc}
\hline Metal & $\begin{array}{c}\text { Certified } \\
\text { concentration } \\
(\mu \mathrm{g} / \mathrm{L})\end{array}$ & $\begin{array}{c}\% \\
\mathrm{RSD}\end{array}$ & $\begin{array}{c}\text { Recovery } \\
(\%)\end{array}$ & $\begin{array}{c}\mathrm{LOQ} \\
(\mathrm{mg} / \mathrm{L})\end{array}$ \\
\hline $\mathrm{Cd}$ & 6.568 & 0.014 & 89.8 & 0.00002 \\
$\mathrm{Cu}$ & 22.76 & 0.004 & 97.7 & 0.0014 \\
$\mathrm{~Pb}$ & 19.63 & 0.010 & 88.6 & 0.0011 \\
$\mathrm{As}$ & 60.45 & 0.001 & 96.9 & 0.0011 \\
$\mathrm{Ni}$ & 62.41 & 0.001 & 95.9 & 0.0019 \\
$\mathrm{Cr}$ & 20.40 & 0.000 & 87.4 & 0.0004 \\
$\mathrm{Hg}$ & 10.00 & 0.010 & 92.4 & 0.0004 \\
\hline$*$ & RSD-relative standard & deviation; LOQ-limit of \\
quantification
\end{tabular}

The blanks and standards were analyzed with the same methods as samples. Blanks did not contain detectable amounts of the analyzed metals.
In order to verify the validity of the measurements, standard reference materials, NIST SRM 1643f - Trace Elements in Water (for $\mathrm{Cd}, \mathrm{Cr}, \mathrm{Cu}, \mathrm{Ni}, \mathrm{Pb}$ and $\mathrm{As}$ ) and NIST SRM 3133 - Mercury (Hg) Standard Solution were used. The recovery was calculated as the percentage of the certified concentration of a metal in the standard reference material determined during the analytical procedure. Analytical method parameters are presented in Table 2.

\section{Analysis of PCBs}

For the determination of PCBs in the analyzed samples Abraxis PCB kit was used. This kit is based on the principles of the enzyme linked immunosorbent assay (ELISA) and is intended to use for the determination of PCBs in water samples.

Samples were prepared for the analysis and analyzed according to a procedure provided by the manufacturer of the kit. In brief, after collecting, samples were diluted and filtered using the glass fiber syringe filter $(0.45 \mu \mathrm{m})$. Aliquots $(50 \mu \mathrm{L})$ of samples were transferred to a well of the microtiter plate and mixed with the enzyme conjugate solution (the horseradish peroxidase labeled PCB analog), antibody solution (rabbit anti-PCB), substrate (colour) solution (hydrogen peroxide and 3,3',5,5'-tetramethylbenzidine in organic base) and stop solution (0.5\% sulfuric acid) in consecutive steps following the provided protocol (Abraxis, 2018).

Results of testing (i.e., content of PCBs) are expressed as Aroclor $1254(\mu \mathrm{g} / \mathrm{L})$.

As a part of the quality control the kit has included a control solution (approximately $5 \mu \mathrm{g} / \mathrm{L}$ of PCB) that is included in every run and handled in the same way as samples. For the determination of the concentration of PCBs in samples, standard solutions of PCBs (as Aroclor 1254) provided within the kit were used $(0,1,5,25,100$, $250 \mu \mathrm{g} / \mathrm{L})$. Calibration curve is constructed by plotting the $\operatorname{logit} \mathrm{B} / \mathrm{B}_{0}$ for each standard versus the natural logarithm of the corresponding PCB concentration.

Logit value is calculated using equation 1 :

$\operatorname{Logit} B / B_{0}=\log \frac{\frac{A}{A 0}}{1-\frac{A}{A 0}}$

where $A_{0}$ is average absorbance value for the negative control (standard concentration 0), and $\mathrm{A}$ is average absorbance value for the standard/sample.

\section{RESULTS AND DISCUSSION}

The content of metals determined in water samples $(\mu \mathrm{g} / \mathrm{L})$ is presented in Table 3. with side-by-side view of the maximum allowable concentrations (MAC) and target values (TV) for the specific metals proposed in the Council Directive 75/440/EEC concerning the quality required of the surface water intended for the abstraction of drinking water in the Member States (EC, 1975), Decision on characterization of surface and underground waters, reference conditions and parameters for the estimation of the water status and water monitoring in 
FBiH (Decision, 2014), EU Directive 2013/39/EU on environmental quality standards in the field of water policy (EC, 2013) and Dutch environmental quality standards (EQS) for surface water and sediments (Warmer and van Dokkum, 2002).

Table 3. The concentration of metals $(\mu \mathrm{g} / \mathrm{L})$ in water samples and maximum allowable concentrations defined by FBiH legislation and EU directives

\begin{tabular}{|c|c|c|c|c|c|c|c|}
\hline \multirow{2}{*}{ Sample } & \multicolumn{7}{|c|}{ Metals $(\mu \mathrm{g} / \mathrm{L})$} \\
\hline & $\mathrm{Pb}$ & $\mathrm{Cd}$ & As & $\mathrm{Cu}$ & $\mathrm{Cr}$ & $\mathrm{Ni}$ & $\mathrm{Hg}$ \\
\hline M1 & $36.58 \pm 0.214$ & $0.283 \pm 0.014$ & $1.386 \pm 0.023$ & $3.117 \pm 0.141$ & $1.255 \pm 0.001$ & $6.920 \pm 0.017$ & $1.075 \pm 0.035$ \\
\hline M2 & $8.573 \pm 0.065$ & $0.024 \pm 0.000$ & $1.474 \pm 0.001$ & $2.267 \pm 0.047$ & $1.129 \pm 0.000$ & $6.920 \pm 0.030$ & $2.495 \pm 0.008$ \\
\hline M3 & $6.790 \pm 0.157$ & $0.031 \pm 0.001$ & $1.892 \pm 0.003$ & $3.202 \pm 0.004$ & $0.859 \pm 0.059$ & $10.43 \pm 0.001$ & $6.098 \pm 0.003$ \\
\hline M4 & $7.532 \pm 0.010$ & $0.064 \pm 0.000$ & $2.349 \pm 0.003$ & $4.175 \pm 0.038$ & $0.558 \pm 0.049$ & $7.900 \pm 0.020$ & $3.893 \pm 0.011$ \\
\hline M5 & $18.16 \pm 0.000$ & $0.066 \pm 0.000$ & $3.518 \pm 0.003$ & $2.724 \pm 0.016$ & $0.453 \pm 0.000$ & $5.813 \pm 0.020$ & $5.113 \pm 0.018$ \\
\hline \multicolumn{8}{|l|}{ Limits } \\
\hline $\begin{array}{c}\text { 75/440/EEC } \\
(\mathrm{mg} / \mathrm{L})\end{array}$ & 0.05 & 0.005 & 0.05 & 0.05 & 0.005 & - & 0.001 \\
\hline \multicolumn{8}{|l|}{ Decision FBiH } \\
\hline $\begin{array}{c}\text { MAC/EQS } \\
(\mu \mathrm{g} / \mathrm{L})\end{array}$ & $7.20^{\mathrm{a}}$ & $\leq 0.45-1.50$ & 20.0 & $1.10-8.80^{\mathrm{b}}$ & 10.0 & $20.0^{\mathrm{a}}$ & 0.07 \\
\hline $\begin{array}{c}2013 / 39 / \mathrm{EU} \\
(\mu \mathrm{g} / \mathrm{L})\end{array}$ & 14.0 & $0.45-0.60$ & & & & 34 & 0.07 \\
\hline $\begin{array}{c}\text { Dutch EQS } \\
\text { MAC }(\mu \mathrm{g} / \mathrm{L})\end{array}$ & 220 & 2.0 & 32.0 & 3.80 & 84.0 & 6.30 & 1.20 \\
\hline $\begin{array}{c}\text { Dutch EQS } \\
\text { TV }(\mu \mathrm{g} / \mathrm{L})\end{array}$ & 5.30 & 0.40 & 1.30 & 1.10 & 2.40 & 4.10 & 0.07 \\
\hline
\end{tabular}

The content of all metals except $\mathrm{Hg}$ at each of five locations was lower than limits defined in the Council Directive 75/440/EEC. The concentration of $\mathrm{Hg}$ recorded at location $1(1.075 \mu \mathrm{g} / \mathrm{L})$ was slightly higher than the defined limit $(1 \mu \mathrm{g} / \mathrm{L})$, while on the other four locations concentrations were two to six times higher than the limit values (Table 3).

Beside $\mathrm{Hg}$ the most abundant metals at all locations were $\mathrm{Pb}$ and $\mathrm{Ni}$. The highest content of $\mathrm{Pb}$ was found at locations 1 and 5 (36.58 and $18.16 \mu \mathrm{g} / \mathrm{L}$, respectively), while the highest concentration of $\mathrm{Ni}$ was found in samples from the locations 3 and 4 (10.43 and 7.90 $\mu \mathrm{g} / \mathrm{L}$, respectively).

The concentration of $\mathrm{Pb}, \mathrm{As}, \mathrm{Cu}$ and $\mathrm{Ni}$ in all samples from all 5 locations were higher than target values defined in Dutch EQS (Table 3). Measured concentration of $\mathrm{Cu}(4.175 \mu \mathrm{g} / \mathrm{L})$ in sample from the location 4 was higher than MAC defined in Dutch EQS $(3.8 \mu \mathrm{g} / \mathrm{L})$, as well as concentrations of $\mathrm{Ni}$ at locations 1 $4(>6.3 \mu \mathrm{g} / \mathrm{L})$.

The concentration of $\mathrm{Hg}$ at all 5 locations was slightly higher than MAC defined in Directive 2008/105/EC and target value defined in Dutch EQS $(0.07 \mu \mathrm{g} / \mathrm{L})$ and two to five times higher than MAC defined in Dutch EQS (Table 3).

Concentration of $\mathrm{Cd}$ at all five locations was well below all aforementioned limits.

Comparing the obtained results to the legislation in $\mathrm{FBiH}$, concentrations of $\mathrm{As}, \mathrm{Cd}, \mathrm{Cu}, \mathrm{Cr}$ and $\mathrm{Ni}$ were bellow MAC or annual average, while concentration of
$\mathrm{Hg}$ at all five locations was almost two orders of magnitude higher than MAC $(0.07 \mu \mathrm{g} / \mathrm{L})$. Concentration of $\mathrm{Pb}$ was slightly below annual average value (6.79 $\mu \mathrm{g} / \mathrm{L}$ vs $7.2 \mu \mathrm{g} / \mathrm{L}$ ) only at one location (M3).

Results of our measurement were also compared with the limits defined in Directive on classification of the surface water and water bodies categorization in Republika Srpska (RS) (Directive, 2001). Maximum permitted levels for inorganic substances (metals and metalloids) for the class II and III (equivalent to class II for the Lake Modrac) are presented in Table 4.

Table 4. Maximum permitted levels for inorganic substances (metals) for the water bodies class II and III

\begin{tabular}{lll}
\hline Metals (total) & class II $(\mu \mathrm{g} / \mathrm{L})$ & class III $(\mu \mathrm{g} / \mathrm{L})$ \\
\hline $\mathrm{As}$ & $10-20$ & $20-40$ \\
$\mathrm{Cd}$ & $0.05-1.0$ & $1.0-2.0$ \\
$\mathrm{Cr}$ & $5-15$ & $15-30$ \\
$\mathrm{Cu}$ & $5-15$ & $15-50$ \\
$\mathrm{Ni}$ & $0.05-1.0$ & $1.0-2.0$ \\
$\mathrm{~Pb}$ & $0.1-0.5$ & $0.5-2.0$ \\
$\mathrm{Hg}$ & $0.1-0.2$ & $0.2-0.5$ \\
\hline
\end{tabular}

Registered concentrations of $\mathrm{As}, \mathrm{Cr}, \mathrm{Cu}$ and $\mathrm{Cd}$ in all analyzed samples (Table 3) were bellow permitted limits defined in aforementioned Directive (Table 4), while the concentrations of $\mathrm{Pb}, \mathrm{Ni}$ and $\mathrm{Hg}$ were slightly higher than limits in all analyzed samples. 
There is almost no data on contamination of the Lake Modrac with heavy metals and organic pollutants published in the literature. Comparing the obtained results in this study with the study conducted in 2007 on the presence of heavy metals at accumulation Lake Modrac, average concentration of $\mathrm{Pb}$ and $\mathrm{Cd}$ measured in this study was two to ten times lower, while concentration of $\mathrm{Cu}$ was in average two to three times higher (Đonlagić, Odobašić, Bratovčić, 2007).

Overall average contents of $\mathrm{Pb}, \mathrm{Ni}$ and $\mathrm{Cd}$ registered in this study at locations M1 and M5 $(27.37 \mu \mathrm{g} / \mathrm{L} ; 6.37$ $\mu \mathrm{g} / \mathrm{L}$ and $0.283 \mu \mathrm{g} / \mathrm{L}$, respecitvelly), were lower than the results of the monitoring of Lake Modrac conducted in 2019 at the same locations $(143.88 \mu \mathrm{g} / \mathrm{L} \mathrm{Pb} ; 8.28 \mu \mathrm{g} / \mathrm{L}$ $\mathrm{Cd}$ and $43.02 \mu \mathrm{g} / \mathrm{L} \mathrm{Ni}$ ) (Đozić and Alihodžić, 2019). Average concentrations of As $(<0.05 \mu \mathrm{g} / \mathrm{L})$ and $\mathrm{Hg}$ $(<0.0001 \mu \mathrm{g} / \mathrm{L})$ reported by this study were much lower than our results $(2.45 \mu \mathrm{g} / \mathrm{L}$ As and $3.09 \mu \mathrm{g} / \mathrm{L} \mathrm{Hg})$.

In comparison to some other lake waters pollution in various countries, including Balkan region, our result are slightly higher than those reported for Lake Kalimanci (Macedonia) and clearly higher than in Skadar Lake (Montenegro), Kralkizi Reservoir, Dickle Reservoir, Batman Reservoir and Isikli Lake (Turkey) for all tested metals (Sibal and Espino, 2018).

Significant positive correlation was found for $\mathrm{Pb}$ and $\mathrm{Cd}$ concentrations $(\mathrm{r}=0.953, \mathrm{p}=0.012)$, and significant negative correlation for $\mathrm{As}$ and $\mathrm{Cr}(\mathrm{r}=-0.911, \mathrm{p}=0.032)$. Polichlorinated biphenyls (PCBs) in the samples from the accumulation Lake Modrac were determined using commercial ELISA kit. Results of measurement were expressed as content of Aroclor 1254 and sum of 7 indicator PCBs (congeners CB 28, CB 52, CB 101, CB 118, CB 138, CB 153 and $\mathrm{CB}$ 180) and presented in Table 5.

Table 5. Concentration of PCBs in analyzed samples from accumulation lake Modrac

\begin{tabular}{ccc}
\hline Sample & Aroclor $1254(\mu \mathrm{g} / \mathrm{L})$ & Sum 7PCBs $(\mu \mathrm{g} / \mathrm{L})$ \\
\hline M1 & $10.35 \pm 1.29$ & $3.23 \pm 0.40$ \\
M2 & $19.84 \pm 7.47$ & $6.19 \pm 2.33$ \\
M3 & $13.79 \pm 4.76$ & $4.30 \pm 1.48$ \\
M4 & $17.94 \pm 5.80$ & $5.59 \pm 1.81$ \\
M5 & $12.91 \pm 2.51$ & $4.03 \pm 0.78$ \\
\hline
\end{tabular}

Aroclor 1254 is one of the several commercial mixtures of PCBs that were extensively used worldwide and still can be measured in environment. Concentrations of PCBs can be presented in few ways depending on the purpose of the analysis and method used. Commercial kits based on ELISA are recognized by Unites States Environmental Protection Agency (US EPA) for the screening purposes and often are used for the detection of presence of PCBs in the water or sediment.

Result of measurements are often expressed as Aroclor content in risk assessment studies, while in most ecotoxicology studies it is important to determine not only total concentration of PCBs, but also congener profile. In that case mostly low chlorinated and high chlorinated congeners $(28,52,101,118,138,153$ and
180) or so called "7 Dutch" or 7PCBs are determined. For that reason, we have recalculated results of the measurements from this study, that were originally expressed as content of Aroclor 1254, to the content of $7 \mathrm{PCB}$, presuming that content of 7PCBs in the commercial Aroclor 1254 mixture is $31.2 \%$. According to Risso et al. (2016), it is possible to establish quantitative relationship between any single Aroclor mixture and the sum concentration of the PCB congeners (Risso, Magherini, Ottonelli, et al., 2016).

Presented results exceed the limit values of $0.014 \mu \mathrm{g} / \mathrm{L}$ for the class III water established by ECE (Economic Commission for Europe) Standard Statistical Classification of Surface Freshwater Quality for the Maintenance of Aquatic Life (UN/ECE, 1992). Previously mentioned, Directive on classification of the surface water and water bodies categorization in Republika Srpska (Directive, 2001) set limit for the PCBs for class II water at $0.02-0.04 \mu \mathrm{g} / \mathrm{L}$ (expressed as sum of PCBs). Concentrations of PCBs at all five locations exceeded this limit. The total concentration of PCBs ( $\Sigma$ PCBs) determined in the Yangtze River, ranged in $0.04-11 \mathrm{ng} / \mathrm{L}$, and was considered low to moderate polluted (Cui, Dong, Huang, et al., 2020). Comparing to this, water in Lake Modrac can be considered as highly polluted. There is no other data on presence of the organic pollutants in the Lake Modrac, so we could not compare our results with similar studies. Additional surveys are urgently needed in order to evaluate ecological status of the accumulation Lake Modrac. Correlations between metals and PCBs concentrations were not statistically significant.

\section{CONCLUSION}

This is the first survey on levels of organic pollutants namely polychlorinated biphenyls (PCBs) in the accumulation Lake Modrac. The content of PCBs determined in this study exceeded the limit values established by regulatory bodies in $\mathrm{EU}$ and in $\mathrm{BiH}$. Comparing values to test results obtained in other countries, water in the accumulation Lake Modrac can be considered as highly polluted. Regarding the content of heavy metals, the most abundant metals at all five sampling locations were $\mathrm{Pb}, \mathrm{Ni}$ and $\mathrm{Hg}$. Since the results from this study were higher than those reported from other authors for lakes in the region, it can be concluded that Lake Modrac evidently reflects some anthropogenic sources of pollution (possibly coal mining, industry, agricultural and domestic sources). Although, some previous surveys on presence of the heavy metals in Lake Modrac were conducted, results of this study are valuable addition to the existing data enabling the analysis of temporal trend in this area of BiH. Results of this study pointed out necessity of conducting more detailed monitoring of the ecological status of the accumulation Lake Modrac. This especially because of the recorded high content of the organic pollutants, that can pose significant health risk for humans. 


\section{REFERENCES}

Abraxis, www. https://abraxis.eurofinstechnologies.com/media/4640/pcbs-higherchlorinated-elisa-user-guide-530041.pdf $(13 / 6 / 2021)$

Ashrap, P., Meeker, J. D., Sánchez, B. N., Basu, N., Tamayo-Ortiz, M., Solano-González, M., Mercado-Garcia, A., Téllez-Rojo, M. M., Peterson, K. E., Watkins, D. J. (2020). In utero and peripubertal metals exposure in relation to reproductive hormones and sexual maturation and progression among boys in Mexico City. Environmental Health, 19, 124, https://doi.org/10.1186/s12940-020-00672-0

BAS EN 13805:2015. (2015). Foodstuffs-determination of trace elements-pressure digestion. Sarajevo: Institute for Standardization of Bosnia and Herzegovina-ISBIH. (In English)

BAS EN 15586:2005. (2005). Water qualityDetermination of trace elements using atomic absorption spectrometry with graphite furnace. Sarajevo: Institute for Standardization of Bosnia and Herzegovina-ISBIH. (In English)

Cui, X., Dong, J., Huang, Z., Liu, C., Qiao, X., Wang, X., Zhao, X., Zheng, B., Shen, J. (2020). Polychlorinated biphenyls in the drinking water source of the Yangtze River: characteristics and risk assessment. Environmental Sciences Europe, 32, 29, https://doi.org/10.1186/s12302020-00309-6

Decision on characterization of surface and underground waters, reference conditions and parameters for the estimation of the water status and water monitoring in Federation of BiH. (2014). Official Gazette of $\mathrm{FBiH}, 1 / 14$

Directive on classification of the surface water and water bodies categorization in Republika Srpska. (2001). Official Gazette of Republic of Srpska, $42 / 01$

Directive on waterbodies categorization (1967). Official Gazette of SRBiH, 42/67

Đonlagić, N., Odobašić, A., Bratovčić, A. (2007). Influence of Agriculture on Water Quality: Significance of Heavy Metals Monitoring. Agriculturae Conspectus Scientificus, 72 (4), 377 381.

Đozić, A., Alihodžić, H. (2019). Analysis of the physicochemical parameters and presence of the heavy metals in the lake Modrac and River Spreča. Center for Ecology and Energy, Tuzla (In Bosnian)

[EC] European Commission. (1975). Council Directive 75/440/EEC concerning the quality required of surface water intended for the abstraction of drinking water in the Member States. Official Journal of the European Communities, L194/26.

[EC] European Commission. (2000). Directive 2000/60/EC of the European Parliament and of the Council of 23 October 2000 establishing a framework for Community action in the field of water policy. Official Journal of the European Union, L327
[EC] European Commission. (2013). Directive 2013/39/EU of the European Parliament and of the Council of 12 august 2013 amending directives 2000/60/EC and 2008/105/EC as regards priority substances in the field of water policy. Official Journal of the European Union, L226/1.

Harman, C., Grung, M., Djedjibegovic, J., Marjanovic, A., Fjeld, E., Veiteberg Braaten, H. F., Sober, M., Larssen, T., Ranneklev, S. B. (2018). The organic pollutant status of rivers in Bosnia and Herzegovina as determined by a combination of active and passive sampling methods. Environmental Monitoring and Assesment, 190(5), 283, https://doi.org/10.1007/s10661-0186667-6.

Harman, C., Grung, M., Djedjibegovic, J., Marjanovic, A., Sober, M., Sinanovic, K., Fjeld, E., Rognerud, S., Ranneklev, S. B., Larssen, T. (2013). Screening for Stockholm Convention persistent organic pollutants in the Bosna River (Bosnia and Herzogovina). Environmental Monitoring and Assesment, 185(2), 1671-1683.

Institute for chemical engineering (2016). Investigation of the water quality of accumulation Lake Modrac in February 2016. (Unpublished results, in Bosnian).

Kelley, A. S., Banker, M., Goodrich, J. M., Dolinoy, D. C., Burant, C., Domino, S. E., Smith, Y. R., Song, P. X. K., Padmanabhan, V. (2019). Early pregnancy exposure to endocrine disrupting chemical mixtures are associated with infammatory changes in maternal and neonatal circulation. Scientific Reports, 9, 5422, https://doi.org/10.1038/s41598-019-41134-z

Klánová, J., Kohoutek, J., Kostrhounová, R., Holoubek, I. (2007). Are the residents of former Yugoslavia still exposed to elevated PCB levels due to the Balkan wars? Part 1: Air sampling in Croatia, Serbia, Bosnia and Herzegovina. Environment International. 33(6), 719-726.

Kumar, M., Kumar Sarma, D., Shubham, S., Kumawat, M., Verma, V., Prakash, A., Tiwari, R. (2020). Environmental Endocrine-Disrupting Chemical Exposure: Role in Non-Communicable Diseases. Frontiers in Public Health, 8, https://doi.org/10.3389/fpubh.2020.553850

Lee, J., Lee, S., Yu, S., Rhew, D. (2016). Relationships between water quality parameters in rivers and lakes: BOD5, COD, NBOPs, and TOC. Environmental Monitoring and Assesment, 188, 252, DOI 10.1007/s10661-016-5251-1.

Li, Q.Q., Loganath, A., Chong, Y.S., Tan, J., Obbard, J.P. (2006). Persistent organic pollutants and adverse health effects in humans. Journal of Toxicology and Environmental Health, Part A, 69 (21), 1987-2005.

Nwadiuto Amadi, C., Nkeiruka Igweze, Z., Ebere Orisakwe, O. (2017). Heavy metals in miscarriages and stillbirths in developing nations. Middle East Fertility Society Journal, 22, 91-100. 
Omeragic, E., Radosevic, D., Causevic, A., Marjanovic, A., Djedjibegovic, J., Sober, M. (2021). Exposure assessment and risk characterization of metals intake through consumption of wine by population of winemakers in Bosnia and Herzegovina and Croatia. Journal of Food and Nutrition Research, (published online first https://www.vup.sk/en/index.php? mainID $=2$ \&nav $\underline{I D}=34$ \&version $=2 \&$ volume $=0$ \&article $=2222$ )

Reports JP Spreča on results of the water analysis in the accumulation lake Modrac (2017). https://spreca.com/izvjestaji/ (12/6/2021) (in Bosnian).

Sibal, L.N., Espino, M.P. (2018). Heavy metals in lake water: a review on occurrence and analytical determination. International Journal of Environmental Analytical Chemistry, DOI: 10.1080/03067319.2018.1481212

Strategy of the protection of the accumulation Lake Modrac (2012) http://www.vladatk.kim.ba/Ministarstva/MPVS/2 013/Strategija_zastite_akumulacije_Modrac.pdf (10/6/2021) (in Bosnian)
Street, M. E., Angelini, S., Bernasconi, S., Burgio, E., Cassio, A., et al. (2018). Current Knowledge on Endocrine Disrupting Chemicals (EDCs) from Animal Biology to Humans, from Pregnancy to Adulthood: Highlights from a National Italian Meeting International Journal of Molecular $\begin{array}{lll}\text { Science, } & 19 & (6),\end{array}$

1647 , https://doi.org/10.3390/ijms19061647.

UN/ECE. (1992). ECE Standards Statistical Classification of Surface Water Quality for the Maintenance of Aquatic Life" United Nation Economic and Social Council, Statistical Commission and Economic Commission for Europe. Conference of European Statisticians. CES/733, 13 April 1992.

Risso, F., Magherini, A., Ottonelli, M., Magi, E., Lottici, S., Maggiolo, S., Garbarino, M., Narizzano, R. (2016). A comprehensive approach to actual polychlorinated biphenyls environmental contamination. Environmental Science and Pollution Research, 23(9), 8770-8780.

Warmer, H. van Dokkum, R. (2002). Water pollution control in the Netherlands-Policy and practice 2001(2002.009). RIZA, Netherlands 


\section{Summary/Sažetak}

Akumulaciono jezero Modrac je od posebnog značaja kao izvor pitke vode za stanovnike Tuzle i nekoliko okolnih naselja. Najznačajniji izvor kontaminacije akumulacije Modrac organskim polutantima predstavljaju otpadne vode iz domaćinstava i industrije. U ovoj regiji, većina naselja nema adekvatne sisteme odvoda otpadnih voda niti postoje postrojenja za njihov tretman. Ostali potencijalni izvori polutanata su industrijska postrojenja od kojih su najznačajniji rudnici (Banovići, Đurđevik), metalna i drvna industrija, fabrike za proizvodnju plastike, te skladišta nafte i naftnih derivata. Nekoliko prethodno provedenih istraživanja u regionu ukazalo je na značajno prisustvo postojanih organskih polutanata i teških metala, pa je cilj ove studije bio da se provede ispitivanje prisustva odabranih anroganskih $(\mathrm{Cd}, \mathrm{Cr}, \mathrm{Cu}, \mathrm{Hg}, \mathrm{Ni}, \mathrm{Pb}$ i $\mathrm{As})$ i organskih polutanata u vodi akumulacionog jezera Modrac, BiH. Sadržaj polihloriranih bifenila (PCB) određen ELISA testom kretao se u rasponu od 3,23-6,19 ppb (suma 7PCB), dok su najveće koncentracije metala (određene primjenom atomske apsorpcione spektrometrije - grafitne tehnike i živinim analizatorom) na svih pet lokacija uzorkovanja registrovane za olovo $(6,79-36,58 \mu \mathrm{g} / \mathrm{l})$, nikl (5,81-10,43 $\mu \mathrm{g} / \mathrm{l})$ i živu $(1,08-6,10 \mu \mathrm{g} / \mathrm{l})$. 